\title{
Age and composition of the Amanay Seamount, Canary Islands
}

\author{
E. Ancochea \& M.J. Huertas \\ Departamento Petrología y Geoquímica, Facultad. Ciencias Geológicas, Instituto Geología Económica \\ Consejo Superior Investigaciones Científicas - Universidad Complutense, 28040 Madrid, Spain \\ *Corresponding Author (E-mail: huertas@geo.ucm.es)
}

Key words: Amanay Seamount, Eastern Canarian Volcanic Ridge, Oceanic Island Basalts, K-Ar geochronology, Canary Islands

\begin{abstract}
A number of samples have been dredged from the upper parts of Amanay and El Banquete Seamounts, yet volcanic materials have been collected only on Amanay Seamount. Based on textural features and the presence or absence of kaersutite, two main types of olivine pyroxene basaltic rocks have been identified. The rocks are basanites with high enrichment in the most incompatible elements, similar to that displayed by Ocean Island Basalts. Samples from Amanay Seamount formed due to a low degree of melting of an enriched mantle, very similar to that which probably caused the Miocene volcanic activity of Fuerteventura. The age of Amanay volcanic rocks, $15.3 \pm 0.4$ and 13.1 $\pm 0.3 \mathrm{Ma}$, is similar to those of the older volcanic units exposed in the nearby islands (Gran Canaria, Fuerteventura and Lanzarote). This proves the formation of a separate submarine volcanic edifice coeval with the other edifices of the Eastern Canarian Volcanic Ridge. Volcanic activity on the submarine edifice is thought to have ceased at about $13 \mathrm{Ma}$, simultaneous with the adjacent main volcanic construction.
\end{abstract}

\section{Introduction}

The islands of Lanzarote and Fuerteventura represent the emergent crest of the Eastern Canarian Volcanic Ridge that extends north-northeast below sea level subparallel to the African coastline and to the oceanfloor spreading fabric. To the North, the Ridge is connected to Conception Bank (Figure 1A), a submarine volcanic complex situated above $30^{\circ}-31^{\circ} \mathrm{N}$ latitude (Luyendyk and Bunce, 1973; Uchupi et al.,1976; Weigel et al., 1978; Dañobeitia, 1988; Dañobeitia and Collette, 1989).

In the southern part of Fuerteventura two circular shaped seamounts appear west of the Jandía Peninsula. The seamounts were interpreted as corresponding to two volcanic edifices the 'Amanay Submarine Edifice', situated northwest of Jandía, and "El Banquete Submarine Edifice", which occurs southwest of Jandía (Ancochea et al., 1996). The latter edifice is connected to the southern end of Fuerteventura by a flat and shallow platform (Figure 1B and C).
Dredging of Amanay and El Banquete Seamounts was carried out under the scope of the Oceanographic and Hydrographic Research of the Spanish Economic Exclusive Zone (ZEE Project, August 2001) by R/V Vizconde De Eza dealing with the study of the ocean floor around the Canary Islands. The aim of the dredging operations was to collect samples in order to determine both the composition and age of the rocks forming the seamounts.

\section{Amanay and El Banquete}

Amanay and El Banquete Seamounts (Figures 1 and 2) lie to the east of Gran Canaria and close to Fuerteventura. In view of their proximity, they were expected to show common geological characteristics. Both seamounts are similar in size, with a basal diameter of 28-29 km, exceeding $2000 \mathrm{~m}$ in height, and are separated by a narrow channel exceeding $1000 \mathrm{~m}$ in depth. 

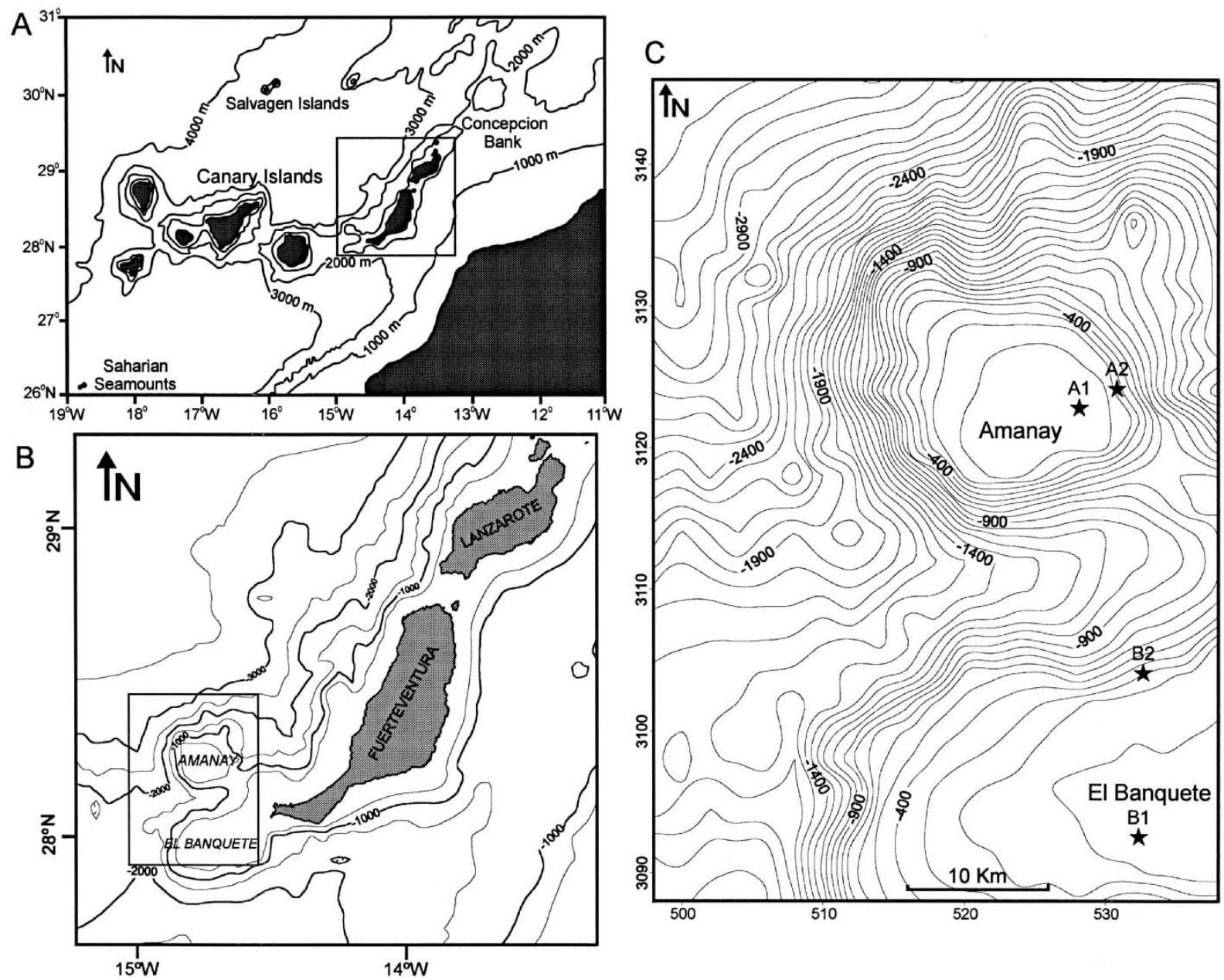

Figure 1. A: Bathymetric map of the Canary Islands and the eastern branch of the Canary Ridge modified after Dañobeitia and Collette (1989). B: Location map of Amanay Seamount using Smith and Sandwell (1997) database and Generic Mapping Tools (Wessel and Smith, 1995). C: Bathymetry map of Amanay Seamount. Contour interval is $100 \mathrm{~m}$. Bathymetry data comes from 'Spanish Economic Exclusive Zone Project'.

\section{Gran Canaria}

The subaerial volcanic history of Gran Canaria began about $15 \mathrm{Ma}$ and was divided into three main phases (Schmincke, 1982). The first phase, the subaerial Miocene phase, started with rapid emission of tholeiitic to weakly alkalic basalts $(\sim 13 \mathrm{Ma})$, followed by rhyolitic/trachytic and phonolitic/trachytic lava flows and ignimbrites. After a period of quiescence (from 8.5 to $5 \mathrm{Ma}$ ) the Pliocene phase consisted of nephelinites, alkali basalts, basanites, tephrites and phonolites, with peak activity at $4 \mathrm{Ma}$. Basanites, tephrites, nephelinites and melilitites make up the Quaternary-Holocene phase, which affected only the northern part of the island.

\section{Fuerteventura}

Two major structural and petrological units are distinguished in Fuerteventura: the Basal Complex and the Subaerial Volcanic Series. As defined by Bravo (1964), Fúster et al. (1968) and Stillman et al. (1975) the Basal Complex is a thick, Cretaceous sedimentary sequence overlain by submarine volcanic rocks and intruded by an intense NNE-SSW trending sheeteddyke swarm, which was formed in association with the emplacement of alkaline plutons. The Basal Complex represents the submarine growth stage of the volcanic complex and the subvolcanic roots (plutons and dykes) of their successive subaerial episodes (Ancochea et al., 1996). 


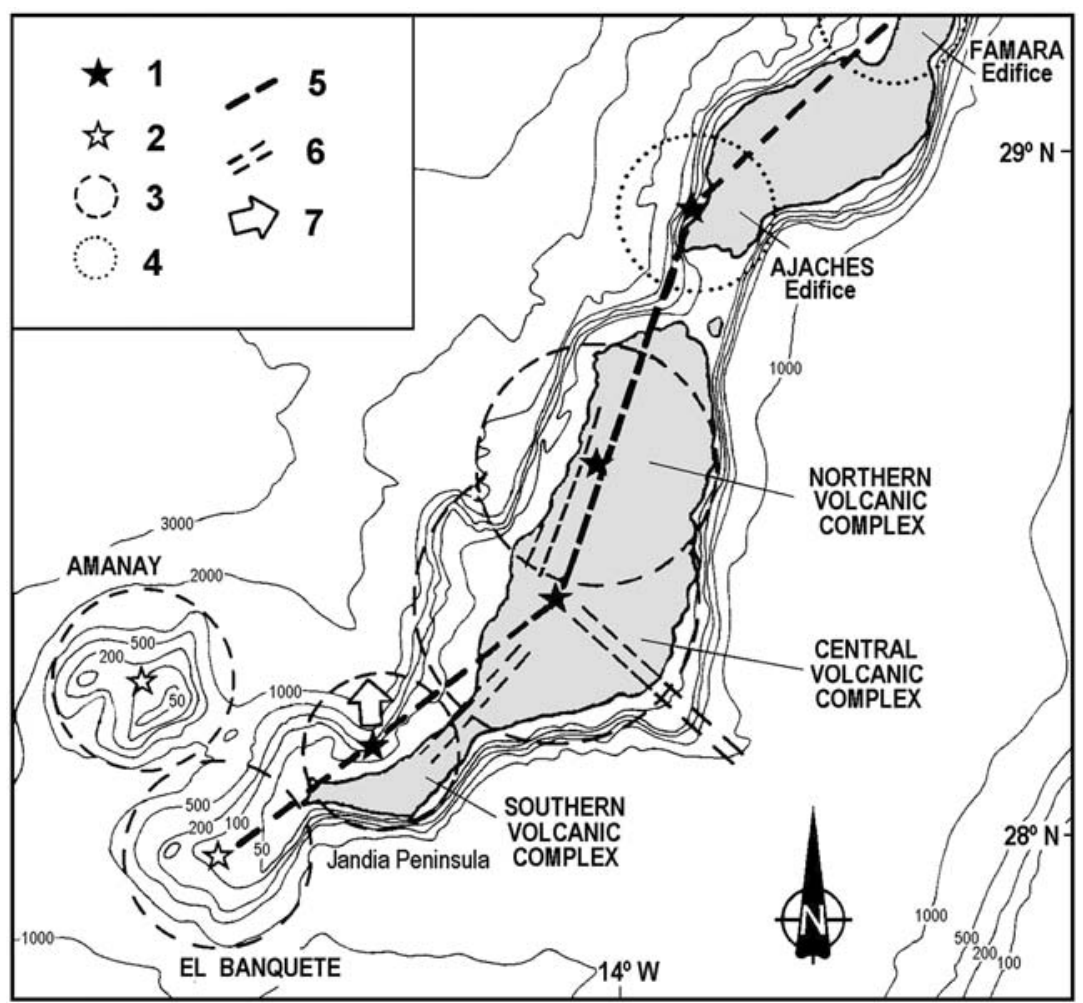

Figure 2. Location of the Volcanic Complexes on Fuerteventura and Lanzarote. $1:$ subaerial emission centers; 2 : submarine emission centers; $3:$ approximated areas occupied by volcanic complexes in Fuerteventura zone; $4:$ approximated areas occupied by volcanic complexes in Lanzarote zone; 5 : alignement of the volcanoes; 6 : main trends of dyke intrusions; 7 : possible landslides. (Ancochea et al., 1996).

Table 1. Age and composition of the Subaerial Volcanic Series of Fuerteventura.

\begin{tabular}{|c|c|c|c|c|}
\hline Units & & & Age (Ma) & Composition \\
\hline \multirow{11}{*}{$\begin{array}{l}\text { Old } \\
\text { Basaltic } \\
\text { series } \\
\text { (Miocene) }\end{array}$} & Southern & Lower & $20.7-19.3$ & Mildly alkaline \\
\hline & Volcanic & Middle & $17.2-15.4$ & Mildly alkaline \\
\hline & Complex & Upper & $15.2-14.2$ & Middle alkaline \\
\hline & $\begin{array}{l}\text { (SVC or } \\
\text { Jandía) }\end{array}$ & Late Formations & ? & Ultra-alkaline \\
\hline & Central & Lower & $>22.5$ & Mildly alkaline \\
\hline & Volcanic & Middle & $22.5-20$ & Middle alkaline \\
\hline & Complex & Upper & $17.5-14.5$ & Middle alkaline \\
\hline & $(\mathrm{CVC})$ & Late Formations & $?-13.2$ & $\begin{array}{l}\text { High alkaline - } \\
\text { ultra-alkaline }\end{array}$ \\
\hline & Northern & Lower & $>22-15.3$ & Middle alkaline- \\
\hline & Volcanic & & & Mildly alkaline \\
\hline & $\begin{array}{l}\text { Complex } \\
\text { (NVC) }\end{array}$ & Upper & $14.3-12.8$ & Alkaline \\
\hline \multicolumn{2}{|c|}{$\begin{array}{l}\text { Recent series } \\
\text { (Pliocene-Quaternary) }\end{array}$} & $\begin{array}{l}\text { Series II, III } \\
\text { and IV }\end{array}$ & $5-0$ & $\begin{array}{l}\text { Middle alkaline } \\
\text { Ultra-alkaline }\end{array}$ \\
\hline
\end{tabular}


Within the Subaerial Volcanic Series, two episodes are distinguishable. The earliest and most important is the Miocene Old Basaltic Series. Ancochea et al. (1991), Cubas et al. (1992), Hernán et al. (1993) and Ancochea et al. $(1993,1996)$ have proposed that the Miocene Old Basaltic Series corresponds to three major volcanoes or volcanic complexes: the Southern Volcanic Complexes (SVC or Jandía), Central Volcanic Complexes (CVC) and Northern Volcanic Complexes (NVC) (Figure 2). Each complex has a separate history, in some cases longer than 10 m.y., with several periods of activity alternating with quiescence accompanied by erosion (Table 1). After a period lasting about 7 m.y. (Coello et al., 1992) and characterized by lack of activity and erosion, new basaltic materials were erupted during emplacement of the Pliocene-Quaternary-Recent series. The importance of this stage is lesser in terms of volume, although it continued until present times.

The geochemical character of the volcanic rocks on Fuerteventura is always alkalic, but alkalinity varies from mildly alkaline (normative hyperstene and olivine but without Ca-poor pyroxene), middle alkaline $(0<$ normative nepheline $\mathrm{Ne}<5)$, high alkaline $(5<\mathrm{Ne}<10)$ and ultra-alkaline $(\mathrm{Ne}>10)$.

\section{Methods}

Rocks were dredged in four sites, two from the Amanay Seamount (A1 and A2) and two from El Banquete Seamount (B1 and B2), one of each pair at shallow depth and the other one at a greater depth along the flank (Figure 1 and Table 2).

Volcanic samples have been dredged only in one site (A1). Fragments of volcanic rocks in this site were abundant and appear to be of uniform petrologic type in hand-specimen. They show minor differences in vesiculation, varying from almost $0 \%$ (non-vesicular) to more than $10 \%$.

Ten samples from site A1 were selected for detailed petrographic and mineralogical study. Two of the samples (number 24 and 32) were considered to represent the main petrographic types and were later analysed. The analysed samples were treated with deionised water to remove seawater. Major and trace element concentrations were determined by ACTLABS laboratories in Ontario (Canada) by X-ray fluorescence spectrometry and by inductively coupled plasma-mass spectrometry (ICP-MS). Samples 24 and 32 were dated by the K/Ar method by Teledyne Iso- topes Laboratory (USA). The material used for dating was represented by 'whole rock' samples of one or two grams, with particle size varying from 0.3 to $1 \mathrm{~mm}$. Argon was extracted by fusion after degassing at moderate temperature in high vacuum and the ${ }^{38} \mathrm{Ar}$ tracer was added to the analysis using a continuous pipetting system. The analytical errors were calculated according to the method of Dalrymple and Lamphere (1969). Converted ages were calculated using the following constants: ${ }^{40} \mathrm{~K} / \mathrm{K}=1.167 \times 10^{-2}$ atoms $\% ; \lambda \varepsilon=0.581 \times 10^{-10} \mathrm{yr}^{-1} ; \lambda_{\beta}=4.962 \times$

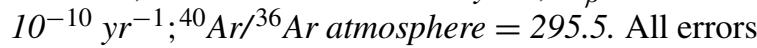
are given at the 2 ' $\sigma$ ' level.

Chemical analyses of minerals was carried out with a JEOL electron microprobe (JXA-8900 M) equipped with four spectrometers at the Universidad Complutense de Madrid. The operating parameters were: $20 \mathrm{~s}$ total counting time, $15 \mathrm{kV}$ accelerating voltage, $20 \mathrm{nA}$ beam current, and $1-5 \mu \mathrm{m}$ beam diameter. Calibration was against standard minerals provided by Department of Mineral Sciences of the Smithsonian Institution (Jarosewich et al., 1980).

\section{Results}

\section{Sedimentary samples}

Sampling site A-1: Medium to coarse sandstones. Well-rounded grains of volcanic rocks and skeletal fragments with isopach sparite cement, interpreted as originally aragonitic in nature (calcite now). In spite of cementation, porosity locally reaches $20 \%$. Fossil content is very high, including bioclasts of Lithothamnium algae (largely branching), echinoids and bivalves. Bivalve shells are moderately penetrated by microborings. The sand is interpreted as having been deposited in agitated, clean, shallow-marine waters (upper shoreface).

Sampling Sites A-2, B-1 and B-2: Bioclastic grainstone with Lithothamnium, gastropods, echinoids, bivalves with superficial microboring, benthic and encrusting Gypsina-like foraminifers. There are some remains of a peloidal matrix. Most grains are coated by isopach sparite to microsparite cement, interpreted as originally aragonitic. There is some intergranular porosity. The environment of deposition was shallowmarine, clean, and characterized by agitated waters (upper shoreface or carbonate platform).

As these rocks were sampled in deep waters, postsedimentary downslope transport is inferred, although 
Table 2. Location of the sampling points

\begin{tabular}{llll}
\hline Seamount & $\begin{array}{l}\text { Sampling } \\
\text { Points }\end{array}$ & $\begin{array}{l}\text { Coordinates } \\
\text { (GPS differential) }\end{array}$ & $\begin{array}{l}\text { Water } \\
\text { Depth (m) }\end{array}$ \\
\hline \multirow{2}{*}{ Amanay } & A1 & $\begin{array}{l}28^{\circ} 13.843^{\prime} \mathrm{N} \\
14^{\circ} 42.773^{\prime} \mathrm{W}\end{array}$ & 27 \\
\cline { 2 - 4 } & $\mathrm{A} 2$ & $\begin{array}{l}28^{\circ} 14.574^{\prime} \mathrm{N} \\
14^{\circ} 41.134^{\prime} \mathrm{W}\end{array}$ & 290 \\
\hline \multirow{2}{*}{ El Banquete } & $\mathrm{B} 1$ & $27^{\circ} 57.442^{\prime} \mathrm{N}$ & 47 \\
& & $14^{\circ} 40.256^{\prime} \mathrm{W}$ & \\
\cline { 2 - 4 } & $\mathrm{B} 2$ & $28^{\circ} 03.707^{\prime} \mathrm{N}$ & 312 \\
& & $14^{\circ} 40.039^{\prime} \mathrm{W}$ & \\
\hline
\end{tabular}

Table 3. K-Ar radiometric age.

\begin{tabular}{lllll}
\hline Sample & $\begin{array}{l}{ }^{40} \mathrm{Ar} * \\
\left(\mathrm{scc} / \mathrm{gr} \times 10^{-5}\right)\end{array}$ & $\%{ }^{40} \mathrm{Ar}^{*}$ & $\% \mathrm{~K}$ & Age (Ma) \\
\hline 24 & 0.056 & 79.8 & 1.10 & $13.1 \pm 0.3$ \\
32 & 0.073 & 78.6 & 1.23 & $15.3 \pm 0.4$ \\
\hline
\end{tabular}

it is possible that subsidence also contributed to moving these rocks to deeper waters.

\section{Volcanic samples (only site A1)}

Petrographic analyses of the rock samples indicate that they are olivine pyroxene basalts, generally nonvesicular or sparsely vesicular.

Two main populations of basaltic rocks can be identified. The most frequent type, represented by sample 24 , is a hypocrystalline porphyritic rock in which the groundmass shows variable crystallinity. The main phenocrysts are clinopyroxene and olivine, but minor amounts of amphibole are also present. The basalts display some evidence of alteration to secondary minerals, and locally a few small vesicles $(<0.3 \mathrm{~mm})$ filled with calcite or zeolites were observed. Fine-grained granular polycrystalline aggregates (up to $1 \mathrm{~cm}$ across) are commonly found; they consist of diopside with variable enstatite contents $(44-47 \%)$ and rare plagioclase; frequently anhedral grains of pargasitic hornblende surround them. The other group of basalts (represented by sample 32) show holocrystalline texture with clinopyroxene and olivine phenocrysts set in a fine-grained matrix. Amphibole is absent in these rocks which, in addition, do not show glass, vesicular texture, microcrystalline

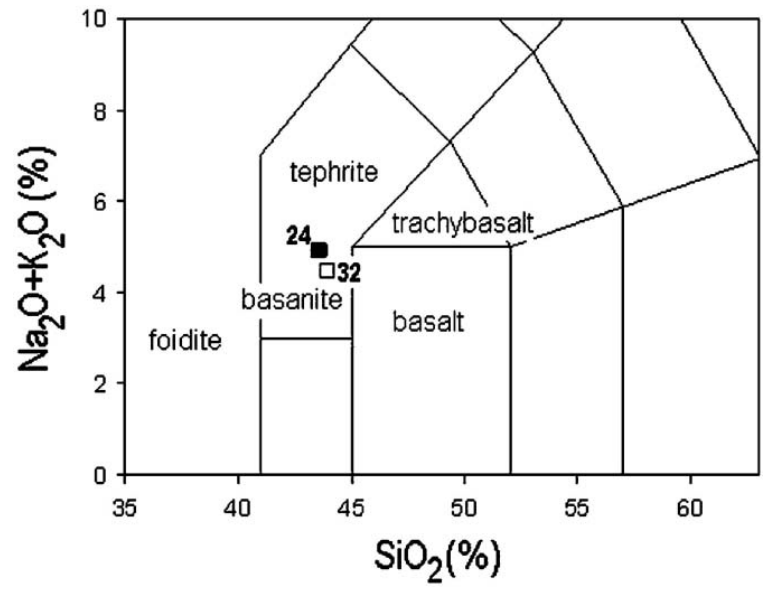

Figure 3. Classification of rocks dredged of Amanay Seamount (24 and 32) using the total alkalis versus silica (TAS).

aggregates or any significant alteration. All these features are clearly different from the basaltic group described above.

In both groups, the clinopyroxene is diopside, which forms subhedral to anhedral zoned and twinned phenocrysts with variable size up to $3 \mathrm{~mm}$ across and appears to be fresh. The diopside exhibits irregular concentric zonation patterns with a range of enstatite content from core to rim (32.5-46.2\%) and cores with variable aegirine contents $(3-14 \%)$. The high $\mathrm{Ca}+\mathrm{Na}$ content determined in diopside is characteristic of the clinopyroxene of alkaline lavas (Leterrier et al., 1982). Olivine is present as subhedral microphenocrysts and is less abundant than clinopyroxene. The olivine phenocrysts display complete alteration to iron oxides and hydroxides, as well as resorption rims.

The amphibole shows some variation in abundance within the samples and varies in size from $1 \mathrm{~mm}$ to $0.1 \mathrm{~mm}$. It occurs both as anhedral phenocrysts and as microcrysts. Larger phenocrysts frequently show resorbed rims with alteration to iron oxides and sphene. In all samples the amphibole is kaersutite and shows an increase in the $\mathrm{Mg} /\left(\mathrm{Mg}+\mathrm{Fe}^{2}\right)$ ratio towards the cores.

The groundmass in both basalt groups typically consists of fresh idiomorphs laths of labradorite to andesine plagioclase $\left(\mathrm{An}_{54}\right.$ to $\left.\mathrm{An}_{43}\right)$, clinopyroxene (diopside) prisms and oxide minerals (magnetite with exsolutions of ilmenite, Cr-bearing magnetite and ilmenite.)

Two K/Ar radiometric determinations (one from each petrographic type) have been carried out from unaltered or slightly altered samples (Table 3). The 


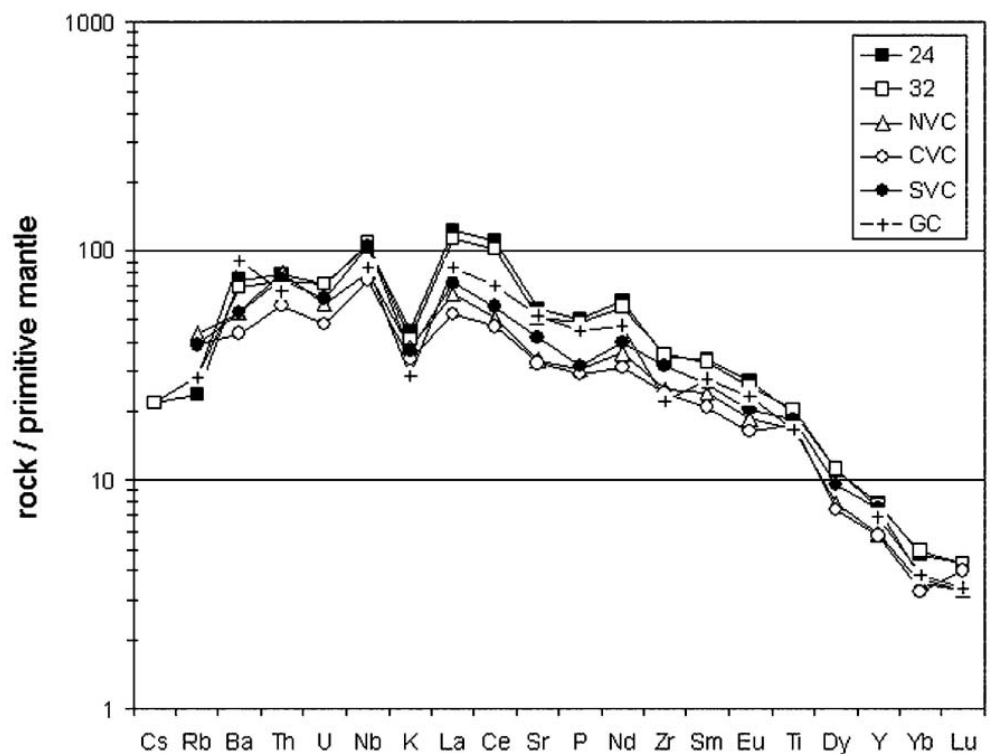

Figure 4. Multi-element diagram for representative samples of rocks dredged of Amanay Seamount (24 and 32). North Volcanic Complex $(N V C)$, Central Volcanic Complex $(C V C)$ and South Volcanic Complex $(S V C)$ of Fuerteventura Island; Miocene basalts of Gran Canaria Island (GC). Trace element concentrations normalized to the composition of upper mantle (Thompson, 1982).

Table 4. Major and trace element data of Amanay rocks (oxides in wt $\%$, trace elements in $\mathrm{ppm}$ )

\begin{tabular}{|c|c|c|c|c|c|c|c|c|}
\hline & 24 & 32 & & 24 & 32 & & 24 & 32 \\
\hline $\mathrm{SiO}_{2}$ & 41.47 & 41.73 & Co & 41 & 39 & $\mathrm{La}$ & 84 & 77.4 \\
\hline $\mathrm{Al}_{2} \mathrm{O}_{3}$ & 12.51 & 12.99 & $\mathrm{Cr}$ & 130 & 94 & $\mathrm{Ce}$ & 196 & 181 \\
\hline $\mathrm{Fe}_{2} \mathrm{O}_{3}$ & 13.58 & 13.84 & Cs & 0.5 & 0.5 & $\operatorname{Pr}$ & 19.9 & 18.4 \\
\hline $\mathrm{MnO}$ & 0.19 & 0.2 & $\mathrm{Cu}$ & 95 & 91 & $\mathrm{Nd}$ & 82.1 & 77.6 \\
\hline $\mathrm{MgO}$ & 7.09 & 7.03 & $\mathrm{Ga}$ & 22 & 22 & $\mathrm{Sm}$ & 15 & 14.5 \\
\hline $\mathrm{CaO}$ & 11.05 & 10.75 & $\mathrm{Nb}$ & 75 & 77 & $\mathrm{Eu}$ & 4.52 & 4.3 \\
\hline $\mathrm{Na}_{2} \mathrm{O}$ & 3.30 & 3.04 & $\mathrm{Ni}$ & 99 & 91 & $\mathrm{Gd}$ & 12.1 & 11.5 \\
\hline $\mathrm{K}_{2} \mathrm{O}$ & 1.35 & 1.24 & $\mathrm{Sc}$ & 25 & 24 & $\mathrm{~Tb}$ & 1.6 & 1.6 \\
\hline $\mathrm{TiO}_{2}$ & 4.24 & 4.38 & V & 352 & 372 & Dy & 8.1 & 8.2 \\
\hline $\mathrm{P}_{2} \mathrm{O}_{5}$ & 1.09 & 1.06 & $\mathrm{Y}$ & 36 & 35 & Ho & 1.4 & 1.3 \\
\hline LOI & 2.93 & 2.68 & $\mathrm{Zn}$ & 120 & 140 & $\mathrm{Er}$ & 3.4 & 3.3 \\
\hline Total & 98.81 & 98.93 & $\mathrm{Zr}$ & 384 & 395 & $\mathrm{Tm}$ & 0.4 & 0.41 \\
\hline $\mathrm{Ba}$ & 519 & 488 & $\mathrm{Ta}$ & 4.9 & 4.9 & $\mathrm{Yb}$ & 2.3 & 2.4 \\
\hline $\mathrm{Rb}$ & 15 & 18 & $\mathrm{Th}$ & 6.7 & 6.3 & $\mathrm{Lu}$ & 0.32 & 0.32 \\
\hline $\mathrm{Sr}$ & 1171 & 1071 & $\mathrm{U}$ & 1.5 & 1.5 & $\mathrm{Hf}$ & 8.3 & 8.6 \\
\hline
\end{tabular}

percentage of ${ }^{40} \mathrm{Ar}^{*}(>20 \%)$ is quite high for rocks with such a low $\mathrm{K}$ content. The chronologic data correspond to the middle Miocene (16.4-11.2 Ma).

The composition of both basalt types is very similar, with $\mathrm{MgO}$ contents around $7 \%$ (Table 4) and both plot in the basanitic field of the Total AlkaliSilica diagram (Le Maitre et al., 1989) (Figure 3). Although the rock looks unaltered, a partial alteration of its composition could have resulted from its location in a marine environment $\mathrm{Ti}, \mathrm{Zr}, \mathrm{Y}$ and $\mathrm{Nb}$ contents, which are thought to be relatively immobile in aqueous fluids, confirm its alkaline character (Winchester and Floyd, 1976; Pearce, 1982). One can come to a similar conclusion from the high Ti/V ratio (73 and 75) and low $\mathrm{TiO}_{2} / \mathrm{P}_{2} \mathrm{O}_{5}$ ratio, which are typical of alkaline rocks (Winchester and Floyd, 1976; Shervais, 
1982). The samples show depletion in heavy rare earth elements (HREE) relative to the light and intermediate rare earth elements $\left((\mathrm{La} / \mathrm{Yb})_{\mathrm{N}}=21.5\right.$ and 23.9 , $(\mathrm{Sm} / \mathrm{Yb})_{\mathrm{N}}=6.95$ and 6.52).

The compositions of the samples normalized to a primordial mantle (Thompson, 1982; Figure 4) reflect enrichment in the more incompatible elements, especially $\mathrm{Nb}, \mathrm{Ta}, \mathrm{La}$ and $\mathrm{Ce} ; \mathrm{K}$ is depleted relative to $\mathrm{Th}, \mathrm{Nb}, \mathrm{Ta}, \mathrm{La}$ and $\mathrm{Ce}$. The pattern is similar to that displayed by Oceanic Island Basalts and Canary Island basalts, showing a strongly negative potassium anomaly and high LREE contents. The low $\mathrm{Ba} / \mathrm{Nb}, \mathrm{Rb} / \mathrm{Nb}$, $\mathrm{K} / \mathrm{Nb}, \mathrm{Th} / \mathrm{Nb}$ and $\mathrm{Ba} / \mathrm{La}$ ratios are similar to those of HIMU basalts (Weaver, 1991).

\section{Comparison with adjacent volcanic edifices}

The volcanic rocks from Amanay show some compositional similarities with other Canary Island volcanic rocks, but they display some significant differences. The Amanay rocks show higher alkali, Zr, Y and REE contents at similar $\mathrm{MgO}$ contents compared to the basalts from the nearby islands (Gran Canaria, Fuerteventura) (Figure 5). The most similar rocks are those from Jandía (SVC), which is the closest volcanic edifice. Both low HREE contents and the high $(\mathrm{Gd} / \mathrm{Yb})_{\mathrm{N}}$ ratios of the Amanay samples suggest low degrees of partial melting, a common feature for Canary Island basalts. $(\mathrm{Gd} / \mathrm{Yb})_{\mathrm{N}}$ ratios are higher (3.8-4.1) than those typical of the Miocene basalts of Gran Canaria (3.1-3.4) but similar to the determined $(\mathrm{Gd} / \mathrm{Yb})_{\mathrm{N}}$ ratios from basalt of La Palma (3.4-4.5) and Fuerteventura (3.4-5.1, average: 4.1). This could indicate that mantle melting may have started at greater depths than in Gran Canaria, but at the same depth as in La Palma and Fuerteventura (Abratis et al., 2001; Ancochea et al., 1993). High $(\mathrm{La} / \mathrm{Yb})_{\mathrm{N}}$ ratios (21.523.9) suggest lower degrees of melting than beneath Gran Canaria (10-19), NVC (14-21) and CVC (9-18) of Fuerteventura. The degree of melting of Amanay is within the range of the Jandía edifice (14-29). $\mathrm{Zr} / \mathrm{Nb}$, $\mathrm{Y} / \mathrm{Nb}$ and $\mathrm{Ba} / \mathrm{Y}$ ratios (5, 0.45 and 14 respectively) are in the same range of those determined in rocks from Fuerteventura, but quite different to the basalts from Gran Canaria $(\mathrm{Zr} / \mathrm{Nb}>6, \mathrm{Y} / \mathrm{Nb}>0.5$ and $\mathrm{Ba} / \mathrm{Y}<10)$, which suggests a more enriched mantle source for the rocks of Amanay and Fuerteventura.

Ages determined from the volcanic samples of Amanay $(13.1 \pm 0.3$ to $15.3 \pm 0.4 \mathrm{Ma})$ indicate that the rocks formed during a time interval in which Gran

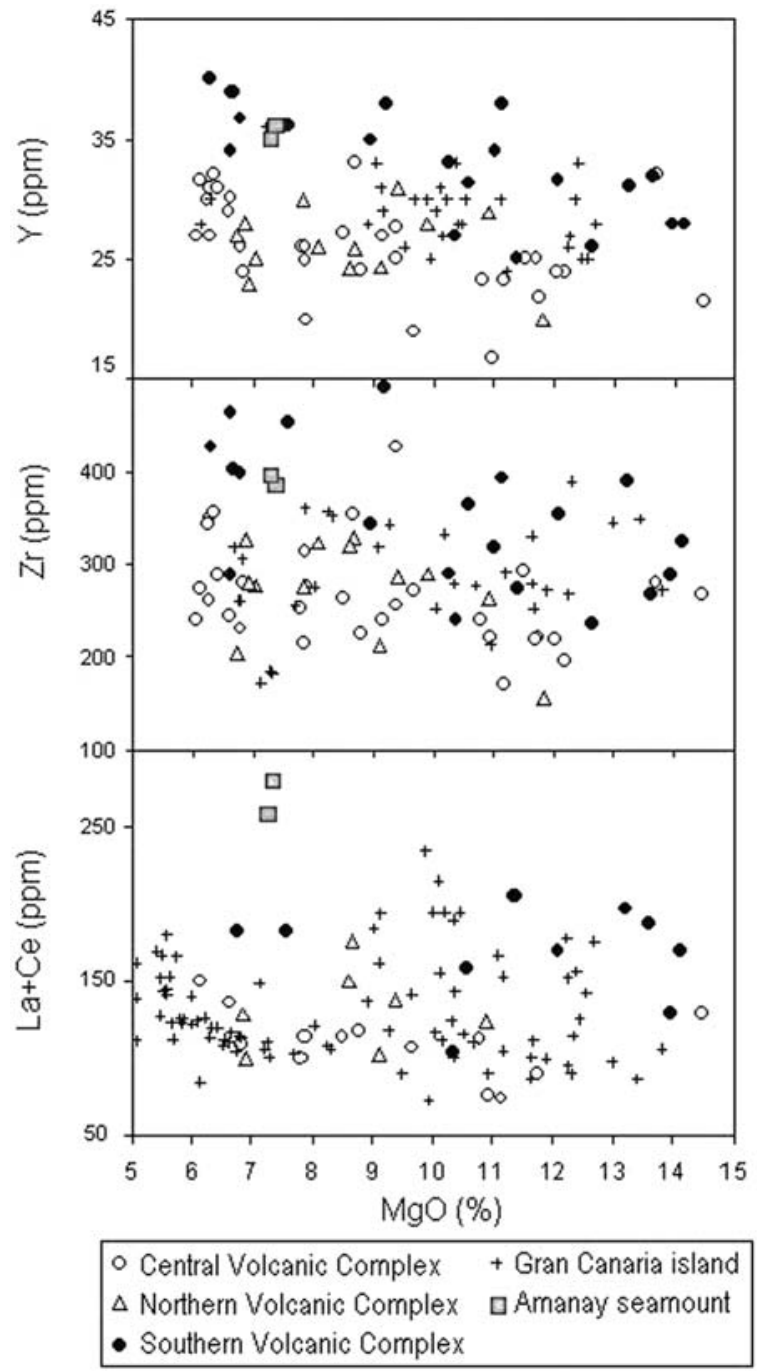

Figure 5. $\mathrm{Zr}, \mathrm{Y}$ and $\mathrm{La}+\mathrm{Ce}$ contents versus $\mathrm{MgO}$ of Amanay, Gran Canaria and Fuerteventura Miocene basalts.

Canaria (Schmincke, 1982), Fuerteventura and the southern part of Lanzarote (Coello et al., 1992) experienced volcanic activity (Figure 6, Table 1). Regarding Gran Canaria, the age is coincident with the first stage of building of the island, with major activity at $13 \mathrm{Ma}$. In this period the volcanic activity is important in the three volcanic complexes of Fuerteventura where the youngest volcanic units were being formed (Ancochea et al., 1996). The oldest age determined in the Amanay basalts is coeval with the lower unit of the NVC, and the youngest age is coeval with the upper unit of the NVC. Regarding the CVC, the upper unit of the edifice was being formed at $15 \mathrm{Ma}$, whilst the volcanic activity (Late Formations, Ancochea et al., 1996) was 


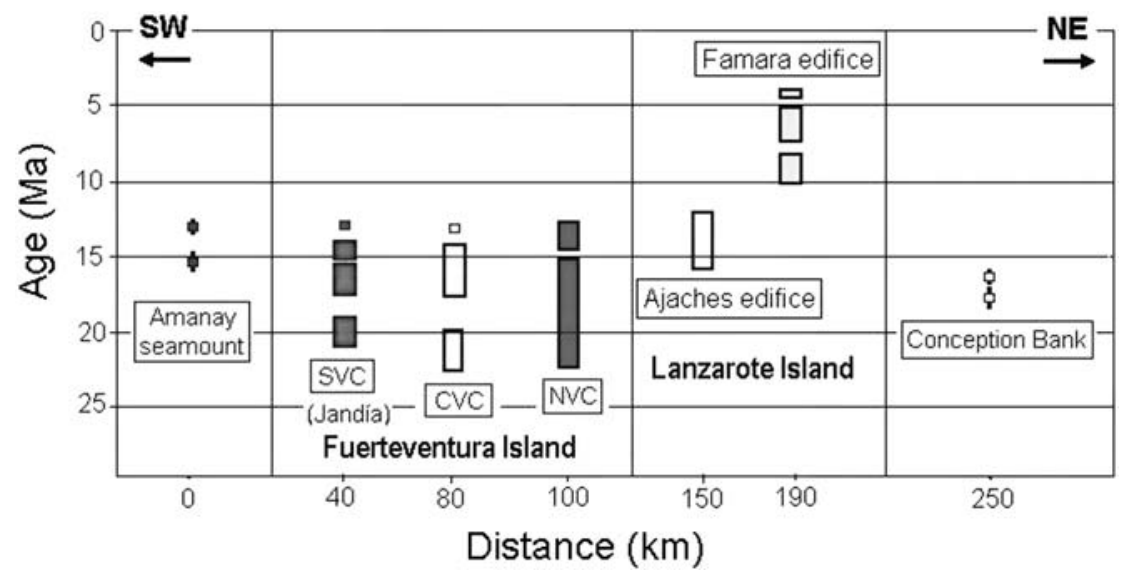

Figure 6. K/Ar radiometric ages from the Amanay rocks and their chronological relationship with the volcanic edifices of the Eastern Ridge of the Canary Islands. $\mathrm{X}$ axis: approximate distance $(\mathrm{km})$ to Amanay Seamount.

residual at $13 \mathrm{Ma}$. Correlation with the SVC shows that the $15.3 \pm 0.4$ age is located at the boundary between the Middle and the Upper SVC whilst the 13.1 $\pm 0.3 \mathrm{Ma}$ age is probably contemporaneous with the late formations. The two determined ages are also coeval with the formation of the Ajaches edifice (15.5 \pm 0.3 to $12.3 \pm 0.3 \mathrm{Ma}$ ) in southern Lanzarote. Ages determined in the Famara edifice (northern Lanzarote) are younger (Coello et al., 1992). Finally, two samples dredged from the Conception Bank (Geldmacher et al., 2001) have yielded ages of $16.64 \pm 0.2 \mathrm{Ma}$ and $17.50 \pm 0.6 \mathrm{Ma}$, somewhat older than the Amanay rocks, but possibly coeval with earlier stages of the building of Amanay Seamount.

\section{Conclusions}

The samples dredged from the Amanay Seamount support the volcanic origin of this edifice. As previously postulated by Ancochea et al. (1993, 1996), the Amanay Seamount is a submarine edifice linked to a row of volcanic edifices extended along a rift subparallel to the African coast-line. The volcanic rocks of Amanay are basanites composed of olivine and pyroxene phenocrysts, erupted at 15.3 and 13.1 Ma.

Two petrographic types are distinguished. The main difference between the two types is the presence or absence of phenocrysts of kaersutite and finegrained granular polycrystalline aggregates of diopside, enstatite, pargasitic hornblende and plagioclase.

The chemical composition of the two basalts collected in Amanay is quite similar. They show OIB and HIMU patterns with clear, strong LREE en- richments. The composition is also similar to the old basaltic rocks of Fuerteventura. The rocks from Amanay derive from a mantle source more enriched and melted at greater depth than that seen in Gran Canaria, but similar to that found in Fuerteventura.

The volcanic rocks of Amanay formed throughout a period (15.3 \pm 0.4 and $13.1 \pm 0.3 \mathrm{Ma})$ of remarkable volcanic activity in the Eastern part of the Canarian Archipelago. During this period, the three volcanic complexes of Fuerteventura and the Southern Edifice of Lanzarote (Los Ajaches) were active. The younger age determined (13.1 Ma) from the Amanay rocks is similar to that shown by the later units belonging to the Fuerteventura and Los Ajaches edifices.

\section{Acknowledgements}

This work was supported by the Projects: DGICYT PB1998-0759, funded by the Spanish Ministry of Science and Technology and UCM - PR1/03-11584. We wish to acknowledge Dr C. Dabrio and Dr J.P. Calvo for a critical reading of the manuscript. The authors wish to thank the officers and crew of the R/V Vizconde de Eza for their aid in dredging the seamounts volcanoes.

\section{References}

Abratis, M., Schmincke, H.U. and Hansteen, T.H., 2002, Composition and evolution of submarine volcanic rocks from the central and western Canary Islands, Int. J. Earth Sci. (Geol Rundsch) 91, 562-582. 
Ancochea, E., Cubas, C.R., Hernán, F. and Brändle, J.L., 1991, Edificios volcánicos en la Serie I de Fuerteventura: rasgos generales del Edificio Central, Geogaceta, 9, 60-62.

Ancochea, E., Brändle, J.L., Cubas, C.R., Hernán, F. and Huertas, M.J. (1993). La Serie I de la isla de Fuerteventura, Memor. $R$. Acad. Cienc. Exac. Fís. Nat. de Madrid, 27, 151 pp.

Ancochea, E., Brändle, J.L., Cubas, C.R., Hernán, F. and Huertas, M.J., 1996, Volcanic Complexes in the Eastern Ridge of the Canary Islands: The Miocene activity of the island of Fuerteventura, J. Vol. Geoth. Res., 70, 183-204.

Bravo, T., 1964, Geología General de las Islas Canarias, T.II. Ed. Goya, Santa Cruz de Tenerife, 592 pp.

Coello, J., Cantagrel, J.M., Ibarrola, E., Jamond, C., Hernán, F., Fúster, J.M., Ancochea, E., Casquet, C., Diaz de Terán, J.R. and Cendrero, A., 1992, Evolution of the Eastern Volcanic Rigde of the Canary Islands Based on New K-Ar Data, J. Vol. Geoth. Res., 53, 251-274

Cubas, C.R., Hernán, F. Ancochea, E. and Brändle, J.L., 1992. El Edificio Sur (Jandía) de la Serie I de Fuerteventura: rasgos generales, Geogaceta, 11, 79-81.

Dalrymple, G.B. and Lanphere, M.A., 1969, Potassium-Argon dating; principles, techniques and applications to geochronology, W.H.Freeman and Co. San Francisco, 258 pp.

Dañobeitia, J.J., 1988, Reconocimiento geofísico de estructuras submarinas situadas al norte y sur del archipiélago Canario, Rev. Soc. Geol. España, 1, 143-155.

Dañobeitia, J.J. and Collette, B.J., 1989, Estudio mediante sísmica de reflexión de un grupo de estructuras submarinas situadas al Norte y Sur del archipiélago Canario, Acta Geol. Hisp., 24, 147163.

Fúster, J.M., Cendrero, A. Gastesi, P., Ibarrola, E. and López Ruiz, J., 1968, Geology and volcanology of Canary Islands, Fuerteventura, Inst. Lucas Mallada. C.S.I.C. Madrid, 243 pp.

Geldmacher, J., Hoernle, K., Bogaard, P.v.d., Zankl, G. and GarbeSchönberg, D., 2001, Earlier history of the $\geq 70$-Ma-old Canary hotspot based on the temporal and geochemical evolution of the Selvagen Archipelago and neighboring seamounts in the eastern North Atlantic, J. Vol. Geoth. Res., 111, 55-87.

Hernán, F., Ancochea, E., Brändle, J.L. and Cubas, C.R., 1993, Características generales en el Edificio Norte de la Serie I de Fuerteventura, Geogaceta, 13, 62-64.

Jarosewich, E.J., Nelen, J.A. and Norberg, J.A., 1980, Reference samples for electron microprobe analysis, Geostandards Newsletters, 4, 43-47.
Le Maitre, R.W., Bateman, P., Dudek, A., Keller, J., Lameyre, J., Le Bas, M.J., Sabine, P.A., Schmid, R., Sorensen, H., Streckeisen, A., Woolley, A.R. and Zanettin, B., 1989, A classification of igneous rocks and glossary of terms, Ed. Blackwell, Oxford, $148 \mathrm{pp}$.

Leterrier, J., Maury, R.C., Thonon, P., Girard, D. and Marchal, M., 1982, Clinopyroxene composition as a method of identification of the magmatic affinities of palaeo-volcanic series, Earth Planet. Sci. Letts., 59, 139-154.

Luyendyk, B. and Bunce, E.T., 1973. Geophysical study of the northwest African Margin of Morocco, Deep Sea Res., 20, 537-549.

Schmincke, H.U., 1982, Volcanic and chemical evolution of the Canary Islands, In V.Von Rad et al., (Editors), Evolution of the Passive Margin of NW Africa. Springer, Heidelberg, 273-306.

Pearce, J.A., 1982, Trace element characteristics of lavas from destructive plate boundaries. In R.S. Thorpe (Editor), Andesites: orogenic andesites and related rocks. Chichester: Wiley, 525548.

Shervais, J.W., 1982, Ti-V plots and the petrogenesis of modern and ophiolitic lavas, Earth Planet. Sci. Letts., 59, 101-118.

Smith, W.H.F. and Sandwell, D.T., 1997, Global seafloor topography from satellite altimetry and ship depth soundings, Science, 277, 1957-1962.

Stillman, C.J., Fúster, J.M., Bennell Baker, M.J., Muñoz, M., Smewing, J.D and Sagredo, J., 1975, Basal complex of Fuerteventura is an oceanic intrusive complex with rift-system affinities, Nature, 257, 469-470.

Uchupi, E., Emery, K.O., Bowin, C.O and Phillips, J.D., 1976, Continental margin of Western Africa: Senegal to Portugal, Am. Assoc. Petrol. Geol. Bull., 60, 809-878.

Thompson, R.N., 1982, British Tertiary volcanic province. Scott, $J$. Geol., 18, 49-107

Weaver, B.L., 1991, The origin of ocean island basalt end-member composition: trace element and isotopic constraints, Earth Planet.Sci. Letts., 104, 381-397.

Weigel, W., Goldflam, P. and Hinz, K., 1978, The Crustal structure of the Conception Bank. Mar, J. Geophys. Res., 3, 381-392.

Wessel P. and Smith W.H.F., 1995, New Version of the Generic Mapping Tools (GMT), http:/www.agu.org/eos_els, American Geophysical Union.

Winchester, J.A. and Floyd, P.A., 1976, Geochemical magma type discrimination; application to altered and metamorphosed basic igneous rocks, Earth Planet. Sci. Letts. 28, 459-469. 